\title{
Determination of metals in medicinal plants highly consumed in Brazil
}

\author{
Alexandre Soares Leal',*, Guilherme Prado², Tatiana Cristina Bomfim Gomes ${ }^{1}$, Fernanda Peixoto \\ Sepe ${ }^{1}$, Ilza Dalmázio ${ }^{1}$
}

${ }^{1}$ Center for Development of Nuclear Technology, Belo Horizonte, Brazil, ${ }^{2}$ Ezequiel Dias Foundation, Belo Horizonte, Brazil

\begin{abstract}
In this work, samples of the medicinal plants: Boldo (Peumus boldus), Castanha da Índia (Aesculus hippocastanum), Chá Verde (Camelia sinensis), Erva Cidreira (Melissa officinalis), Espinheira Santa (Maytenus ilicifolia), Guaraná (Paullinia cupana), Maracujá (Passiflora sp.), Mulungu (Erythrina velutina), Sene (Cassia angustifolia) and Valeriana (Valeriana officinalis) were evaluated BY using the Neutron Activation Analysis technique $\left(\mathrm{NAA}-\mathrm{k}_{0}\right.$ ) in order to determine the levels of metals and other chemical contaminants. The results showed the presence of non essential elements to the human body. The diversity of chemical impurities found even at low concentration levels, considering the potential for chronic toxicity of these elements, reinforces the need to improve the implementation of good practices by growers and traders, and the hypothesis of lack of quality control in plant products.
\end{abstract}

Uniterms: Neutron activation analysis. Medicinal plants. Metals/determination in medicinal plants. Chemical contaminants. Plant products/quality control.

\begin{abstract}
Neste trabalho, amostras de Boldo (Peumus boldus), Castanha da Índia (Aesculus hippocastanum), Chá Verde (Camelia sinensis), Erva Cidreira (Melissa officinalis), Espinheira Santa (Maytenus ilicifolia), Guaraná (Paullinia cupana), Maracujá (Passiflora sp.), Mulungu (Erythrina velutina), Sene (Cassia angustifolia) e Valeriana (Valeriana officinalis) foram investigadas utilizando a técnica Análise por Ativação Neutrônica (AAN- $\mathrm{k}_{0}$ ), a fim de se determinar os teores de metais e outros elementos químicos contaminantes. Os resultados revelaram a presença de elementos não essenciais ao organismo humano. A diversidade de impurezas químicas encontradas, mesmo em níveis de baixa concentração, considerando o potencial de toxicidade crônica desses elementos, reforça a necessidade de melhorias na aplicação de boas práticas pelos produtores e comerciantes e a hipótese de falta de controle de qualidade nos produtos vegetais.
\end{abstract}

Unitermos: Análise por ativação neutrônica/análise quantitativa. Plantas medicinais. Metais/determinação em plantas medicinais. Contaminantes químicos/determinação em plantas medicinais. Produtos vegetais/ controle de qualidade.

\section{INTRODUCTION}

The consumption of medicinal plants for therapeutic purposes is recognized as one of the earliest forms of medical practice of mankind. This use tends to grow over the years, both in developed and developing countries (Veiga, Pinto, Maciel, 2005; Viegas, Bolzani, Barreiro, 2006; WHO, 2004).

\footnotetext{
*Correspondence: A. S. Leal. Centro de Desenvolvimento da Tecnologia Nuclear. Av. Antônio Carlos, 6.627, 31270-901 - Belo Horizonte - MG, Brasil. E-mail: asleal@cdtn.br
}

In Brazil, the high cost of manufactured drugs, the dissatisfaction with traditional medicine, the difficulties to access the health public system are some factors of the increasing use of medicinal plants (Peron et al., 2008; Simões et al., 2003; Souza-Moreira, Salgado, Pietro, 2010; WHO, 2002). However, the lack of an efficient control system and quality assessment of such products may contribute to exacerbate the health public problems in the country (Leal et al., 2006; Veiga, Pinto, Maciel, 2005).

Due to the importance of medicinal plants and herbal medicines and considering the production chain, the Brazilian legislation was recently updated with the 
publication of the RDC (Board Resolution Collegiate) $n^{\circ} 10 / 2010, R D C n^{\circ} 14 / 2010$ and also of the Normative Instruction $n^{\circ} 5 / 2010$ (Brasil, 2010b,c,d). The RDC $n^{\circ}$ $10 / 2010$ provides the registration of herbal medicines and also sets out a list of plant species - selected according to its traditional use - having been standardized, for each species, the therapeutic indications, methods of use, quantities to be eaten and care and restrictions to be observed. Additionally, it was determined the maximum load limit for bacterial, fungal and aflatoxins that may be present in these products, as determined by the World Health Organization (WHO). Some other controls which have been recommended are: the determination of the amount of other contaminants, such as, heavy metals, parts of the plant itself that are not allowed, other medicinal plants, among others (Brasil, 2010a).

Medicinal plants, as well AS the synthetic drugs, have pharmacologically active groups responsible for the desired therapeutic effect in the body. Thus, it becomes necessary to know the composition of the constituents of each plant and assessment of toxicity and their therapeutic potential. The widespread conception among the population that "natural" means "safe" and that drugs of natural origin are harmless and have no risk associated with its use, does not match reality. Some medicinal plants have inherent toxicity and herbal medicines, like any medicine, have side effects that can cause many diseases (Lanini et al., 2009; WHO, 2004). The general belief of the absence of any possible side effects of natural medicines reinforceS the concern with the indiscriminate use of these products (Lanini et al., 2009; Peron et al., 2008). Some factors are directly related to the variation in the content of active compounds present in the plant, such as, the weather and soil conditions. Thus, the quality of the plant material can vary depending on its origin and harvest period as well (Simões et al., 2003). Furthermore, there is a concern about the potential contamination of vegetable drugs, depending on its natural origin (Bugno et al., 2005).

The quality control of the raw materials is a critical step for obtaining herbal medicines with acceptable degree of quality for consumers. It has been observed that the increasing demand for medicinal plants and herbal medicines, by itself, has led to a reduction in the quality of the product offered. The lack of information among producers about the care needed in each stage of production, from the harvest or the obtaining of the raw material to the final processing, and the shortage of trained professionals in the industry, also contribute to the low quality of the products or products that have poor quality (Carvalho et al., 2010; Zaroni et al., 2004). A wide variety of analytical techniques, such as, Atomic Absorption Spectroscopy (AAS), Mass Spectrometry Inductively Coupled Plasma (ICP-MS), High Performance Liquid Chromatography (HPLC) and neutron activation analysis (NAA), have been employed in the evaluation of herbal drugs, as well as IN clinical samples from case studies involving suspicion of heavy metal intoxication (Gautam et al., 2010; Yuan, Chapman, Wu, 2011).

In order to improve the quality of medicinal plants and their derivates in general, Zhang and colleagues (2012) suggested the strict implementation of Guide GFP and harvesting medicinal plants to the national and regional level, this guide was published by the World Health Organization (WHO, 2003) and has been developed in China, and the European Union. Japan was also encouraged to joint to the use of other guides as good manufacturing practices, modern analytical methods and pharmaceutical techniques in production processes and control require investments in research of applicable methodologies to the sector and increase regulation (Zhang et al., 2012).

The lack of quality of raw vegetable materials and their derivates is not a problem exclusively of Brazil (Fitoterápicos, 2010; Yadav, Prajapati, 2011; Zhang et al., 2012). Several studies have shoWN A concern about the presence of contaminants in plants, teas, extracts, powders, herbal products, among others (Alwakeel, 2008; Caldas, Machado, 2004; Carvalho et al., 2010; Hussain et al., 2006; Jabeen et al., 2010; Lokeshappa et al., 2012; Rubio et al., 2012; Vulcano et al., 2008).

The presence of foreign materials in the herbal medicines may compromise the quality of the drug and interfere in their effectiveness and ALSO endanger consumer's health (Balbino, Dias, 2010; Carvalho et al., 2011; Freire, 2005; Melo et al., 2004; Tobias et al., 2007). The major concern for human health is the long-term exposure to chemicals nonessential TO humans, even at low concentrations (Fergusson, 1990; Remington, Genaro, 2000).

Plants have the ability to accumulate metals essential TO their growth and developED from the soil and water - such as, Mg, Fe, Ms, Zn, Cu, Mo and Ni (Langille, MacLean, 1976). Some plants even have the ability to accumulate metals that have no known biological function to them, as $\mathrm{Hg}, \mathrm{Cr}$ and others. The excessive accumulation of metals is toxic to most plants (Memon et al., 2001).

Considering this issue, the aim of this was to investigate the presence of metals and other elements in plant samples in different forms, such as dry extracts, powders and vegetable drugs, by using neutron activation analysis (NAA). 


\section{MATERIAL AND METHODS}

Eleven vegetable samples of medicinal herbs were purchased at Central Market in Belo Horizonte from different suppliers, five of them were dry extracts (DE); three, powders $(\mathrm{P})$ and three, teas $(\mathrm{T})$, as described in Table I.

For identification purposes, the macro and microscopic characterization of powders and dry extracts were performed by the laboratory of the

TABLE I - Samples evaluated and respective characteristic information

\begin{tabular}{|c|c|c|c|c|c|}
\hline Sample & Cientific name* & Family & $\begin{array}{l}\text { Part of the plant. } \\
\text { Method of Using }\end{array}$ & Dosage & Therapeutic Use \\
\hline Boldo (T) & Peumus boldus & Monimiaceae & $\begin{array}{l}\text { Leaves. Infusion: } 1-2 \\
\mathrm{~g}(1-2 \text { tea spoons) } \\
\text { in } 150 \mathrm{~mL} \text { (tea cup) } \\
\text { (Brasil, 2010c) }\end{array}$ & $\begin{array}{l}\text { Use } 1 \text { cup tea, } \\
2 \text { times a day } \\
\text { (Brasil, 2010c) }\end{array}$ & $\begin{array}{l}\text { Treatment of hepatic disorders } \\
\text { and cholelithiasis (Melo et al., } \\
\text { 2004). }\end{array}$ \\
\hline $\begin{array}{l}\text { Castanha da } \\
\text { Índia (DE) }\end{array}$ & $\begin{array}{l}\text { Aesculus } \\
\text { hippocastanum }\end{array}$ & Hippocastanaceae & $\begin{array}{l}\text { Seeds in shell. } \\
\text { Decoction: } 1.5 \mathrm{~g}(1 / 2 \\
\text { tablespoon) in } 150 \mathrm{~mL} \\
\text { (tea cup) (Brasil, 2010c) }\end{array}$ & $\begin{array}{l}\text { Use } 1 \text { cup tea, } 2 \\
\text { times daily, after } \\
\text { meals (Brasil, } \\
\text { 2010c) }\end{array}$ & $\begin{array}{l}\text { Treatment of varicose veins } \\
\text { and hemorrhoids (Martins e } \\
\text { Brandão, 2006). }\end{array}$ \\
\hline $\begin{array}{l}\text { Chá Verde } \\
\text { (DE) }\end{array}$ & $\begin{array}{l}\text { Camelia } \\
\text { sinensis }\end{array}$ & Theaceae & $\begin{array}{l}\text { Leaves. Infusion: } \\
1-2 \mathrm{~g}(1-2 \text { tea spoons) } \\
\text { in } 150 \mathrm{~mL} \text { (tea cup) } \\
\text { (Plantamed, 2013) }\end{array}$ & $\begin{array}{l}\text { Use } 1 \text { cup tea, } 3 \text { or } \\
4 \text { times daily }\end{array}$ & $\begin{array}{l}\text { To reduce levels of cholesterol, } \\
\text { antimicrobial and antioxidant } \\
\text { (Nishiyama et al., 2010). }\end{array}$ \\
\hline $\begin{array}{l}\text { Erva Cidreira } \\
(\mathrm{T})\end{array}$ & $\begin{array}{l}\text { Melissa } \\
\text { officinalis }\end{array}$ & Labiatae & $\begin{array}{l}\text { Worthies flowering. } \\
\text { Infusion: } 2 \text { to } 4 \mathrm{~g} \\
\text { (1-2 dessert spoons) } \\
\text { in } 150 \mathrm{~mL} \text { (tea cup) } \\
\text { (Brasil, 2010c) }\end{array}$ & $\begin{array}{l}\text { Use } 1 \text { cup tea, } 2 \\
\text { or } 3 \text { times daily } \\
\text { (Brasil, 2010c) }\end{array}$ & $\begin{array}{l}\text { Antispasmodic, antipyretic, } \\
\text { anti-inflammatory, diaphoretic, } \\
\text { analgesic and sedative (Julião } \\
\text { et al., 2003). }\end{array}$ \\
\hline $\begin{array}{l}\text { Espinheira } \\
\text { Santa }(P, T)\end{array}$ & $\begin{array}{l}\text { Maytenus } \\
\text { ilicifolia }\end{array}$ & Celastraceae & $\begin{array}{l}\text { Leaves. Infusion: } 1-2 \mathrm{~g} \\
\text { (1-2 tea spoons) in } 150 \\
\mathrm{~mL} \text { (tea cup) (Brasil, } \\
2010 \mathrm{c})\end{array}$ & $\begin{array}{l}\text { Use } 1 \text { cup tea, } 3 \\
\text { or } 4 \text { times daily } \\
\text { (Brasil, 2010c) }\end{array}$ & $\begin{array}{l}\text { Treatment of gastritis and } \\
\text { stomach ulcers (Negri, } \\
\text { Possamai, Nakashima, 2009). }\end{array}$ \\
\hline Guaraná (P) & $\begin{array}{l}\text { Paullinia } \\
\text { cupana }\end{array}$ & Sapindaceae & $\begin{array}{l}\text { Seeds. } 0.5 \text { to } 2 \mathrm{~g} \text { of the } \\
\text { powder (1-4 teaspoons } \\
\text { coffee) (Brasil, 2010c) }\end{array}$ & $\begin{array}{l}\text { Use pure or } \\
\text { diluted in water } \\
\text { (Brasil, 2010c) }\end{array}$ & $\begin{array}{l}\text { Central nervous system } \\
\text { stimulant (Kuskoski et al., } \\
\text { 2005). }\end{array}$ \\
\hline $\begin{array}{l}\text { Maracujá } \\
\text { (DE) }\end{array}$ & Passiflora sp. & Passifloraceae & $\begin{array}{l}\text { Leaves. Infusion: } 3 \mathrm{~g} \mathrm{(1} \\
\text { tablespoon) in } 150 \mathrm{~mL} \\
\text { (tea cup) (Brasil, 2010c) }\end{array}$ & $\begin{array}{l}\text { Use } 1 \text { cup tea, } 1 \\
\text { or } 2 \text { times daily } \\
\text { (Brasil, 2010c) }\end{array}$ & $\begin{array}{l}\text { Treatment of anxiety, insomnia } \\
\text { and stress (Paris et al., 2002). }\end{array}$ \\
\hline Mulungu (P) & $\begin{array}{l}\text { Erythrina } \\
\text { velutina }\end{array}$ & $\begin{array}{l}\text { Leguminosae ou } \\
\text { Fabaceae }\end{array}$ & $\begin{array}{l}\text { Bark. Decoction: } \\
4-6 \mathrm{~g}(2-3 \text { teaspoons }) \\
\text { in } 150 \mathrm{~mL} \text { (tea cup) } \\
\text { (Brasil, 2010c) }\end{array}$ & $\begin{array}{l}\text { Using one cup } \\
\text { tea } 2-3 \mathrm{x} \text { daily } \\
\text { (Brasil, 2010c) }\end{array}$ & $\begin{array}{l}\text { Sudorific, sedative, emollient, } \\
\text { and local anesthetic (Virtuoso } \\
\text { et al., 2005). }\end{array}$ \\
\hline Sene (DE) & $\begin{array}{l}\text { Cassia } \\
\text { angustifolia }\end{array}$ & Febaceae & $\begin{array}{l}\text { Leaves. Leaves. } \\
\text { Infusion: 1-2 g (1-2 tea } \\
\text { spoons) in } 150 \mathrm{~mL} \text { (tea } \\
\text { cup) (Plantamed, 2013) }\end{array}$ & $\begin{array}{l}\text { Use } 1 \text { cup at } \\
\text { bedtime }\end{array}$ & $\begin{array}{l}\text { Treatment of constipation } \\
\text { (Peron et al., 2008). }\end{array}$ \\
\hline $\begin{array}{l}\text { Valeriana } \\
\text { (DE) }\end{array}$ & $\begin{array}{l}\text { Valeriana } \\
\text { officinalis }\end{array}$ & Valerianaceae & $\begin{array}{l}\text { Rhizome and roots. } \\
\text { Infusion or decoction: } 5 \\
\text { to } 15 \mathrm{~g} \text { of fresh root (or } \\
5 \mathrm{~g} \text { of root dry weight) } \\
\text { per liter of water. } \\
\text { (Plantamed, 2013) }\end{array}$ & $\begin{array}{l}\text { Take } 50 \text { to } \\
200 \mathrm{~mL} \text { per day }\end{array}$ & $\begin{array}{l}\text { Treatment of digestive } \\
\text { problems, insomnia, stress, } \\
\text { urinary tract disorders } \\
\text { (Silveira, Bandeira e Arrais, } \\
\text { 2008). }\end{array}$ \\
\hline
\end{tabular}

\footnotetext{
* As informed by the supplier.
} 
TABLE II - Parameters of neutron activation analysis

\begin{tabular}{|c|c|}
\hline Thermal Flux $\left(\mathrm{cm}^{-2} \mathrm{~s}^{-1}\right)$ & $6.4 \times 10^{11}$ \\
\hline \multicolumn{2}{|c|}{$\mathrm{k}_{0}$ - parameters } \\
\hline$f$ & 20.4 \\
\hline$\alpha$ & 0.197 \\
\hline Irradiation time $(\mathrm{h})$ & 8 \\
\hline Detector nominal efficiency $(\%)$ & 50 \\
\hline \multicolumn{2}{|c|}{ Softwares used for: } \\
\hline Acquisition spectra & Genie 2000 (CANBERRA) \\
\hline Spectra Analysis & HyperLab \\
\hline Concentration calculation & KayWin V.2.42 \\
\hline Sample mass (mg) & $200-250$ \\
\hline
\end{tabular}

Microscopy Ezequiel Dias Foundation (FUNED). From the microscopic characterization of dry extracts, it can be observed a large amount of starch in all extracts, and the presence of microorganisms in some samples, which suggests a possible shift in the quality of the acquired samples; however, this issue is not the focus of discussion at the moment.

The investigation of contaminants in the samples was performed by the (NAA- $\mathrm{k}_{0}$ ), which is the most appropriate method for this type of investigation, since it allows to determine the presence and concentration of several elements simultaneously, in trace levels, parts per billion (ppb), without any complex sample preparation. The elemental concentration is obtained through the spectra of the gamma radiation emitted by the elements present in the matrix, which become radioactive after beING irradiated by neutron of a nuclear research reactor (Leal et al., 2006; Menezes, Jacimovic, 2006; Yamashita et al., 2005). The samples were first crushed and sieved, when necessary, homogenized, weighed (approximately $200 \mathrm{mg}$ ) and placed into polyethylene tubes. The irradiation was performed at the TRIGA IPR-R1 reactor of CDTN (Jacimovic, Menezes, 2006; Leal et al., 2008) according TO the conditions and parameters presented in Table II.

\section{RESULTS AND DISCUSSION}

The results of (NAA- $\mathrm{k}_{0}$ ) confirming the presence of several chemical elements: $\mathrm{Al}, \mathrm{As}, \mathrm{Au}, \mathrm{Ba}, \mathrm{Br}, \mathrm{Ca}, \mathrm{Ce}, \mathrm{Cl}$, $\mathrm{Co}, \mathrm{Cr}, \mathrm{Cs}, \mathrm{Fe}, \mathrm{Hf}, \mathrm{Hg}, \mathrm{K}, \mathrm{La}, \mathrm{Mg}, \mathrm{Mn}, \mathrm{Na}, \mathrm{Rb}, \mathrm{Sb}, \mathrm{Sc}, \mathrm{Se}$, $\mathrm{Sm}, \mathrm{Sr}, \mathrm{Th}, \mathrm{V}$ and $\mathrm{Zn}$ - at a wide range of concentrations are presented in the Tables II, III and IV.

From Tables II and III, it can be observed a wide variability in the concentration of the quantified elements. It is not possible to establish any previous relation from the elements or quantify them with the plant or its forms analyzed. This fact could be already expected due to the heterogeneity of the samples acquired from different manufacturers and with particular forms of cultivation and post-harvest processing.

Samples of Erva cidreira (T) and Mulungu (P) showed high concentrations of 13 and 8 elements, respectively, among the 30 ONES analyzed, namely: Al, $\mathrm{As}, \mathrm{Au}, \mathrm{Ca}, \mathrm{Cl}, \mathrm{Cr}, \mathrm{Cs}, \mathrm{Fe}, \mathrm{K}, \mathrm{Mg}, \mathrm{Mn}, \mathrm{Sc}$ to $\mathrm{Zn}$ to Erva cidreira and $\mathrm{Ba}, \mathrm{Ce}, \mathrm{Co}, \mathrm{Hf}, \mathrm{La}, \mathrm{Nd}, \mathrm{Sr}$ and $\mathrm{Th}$ to the Mulungu.

The presence of several non essential elements to the human body, such as, Ba, Ce, Hf, La, Sb, Sc, Sm, Sr and $\mathrm{Th}$ can be attributed to the production and harvest processes, the handling of dry extracts, powders and teas from the soil or THE atmosphere contamination (Ernst, 2002; Fraga, 2005; Zhang et al., 2012). The methods used in packaging and transportation of medicinal plants and related products also constitute important steps in critical contamination by heavy metals and pesticides (Carvalho et al., 2010; Freire, 2005).

The element $\mathrm{Ca}$ and its relatively high concentration can be expected in aromatic plants, as well as for the elements $\mathrm{Cl}, \mathrm{Fe}, \mathrm{K}, \mathrm{Mg}, \mathrm{Mn}, \mathrm{Na}$ and $\mathrm{Zn}$, naturally found in organic matrixes. In general, concentrations of metals like $\mathrm{Al}, \mathrm{Ag}, \mathrm{Cd}, \mathrm{Hg}, \mathrm{Sb}, \mathrm{Sn}$, involved in the biological cycle are very low, this relatively small variations of some elements might cause serious damage to humans and other living organisms, thereby, systematic investigations and the IR control are necessary (Dospatliev et al., 2012).

The toxic effects of metals for the human health can be dependent on several variables, such as, the affected organism, their temporal condition and the exposure parameters. The results presented here suggest the need to assess the quality of herbal medicines commercialized due to the potential toxicity of the elements found in them (Azevedo, Chasin, 2003). The toxicological effects of these elements are very difficult to predict, because they are not mentioned in the reference elements of the nutritional diet (Carvalho et al., 2006).

\section{CONCLUSION}

The analysis of the ten different most consumed medicinal herbs in Brazil by the (NAA- $\mathrm{k}_{0}$ ) method showed the presence of several non essential elements for the human health like, As, Au, Ba, Ce, Co, Cr, Cs, Hf, La, $\mathrm{Rb}, \mathrm{Sb}, \mathrm{Sm}, \mathrm{Sr}$, Th and $\mathrm{V}$, in concentrations varying from 0.02 to $540\left(\mathrm{mg} \mathrm{kg}^{-1}\right)$. These concentrations are in general, 
TABLE III - Elemental concentration ( $\mathrm{mg} \mathrm{kg}^{-1}$ ) of the samples: Castanha da Índia, Maracujá and Chá Verde (DE); Espinheira Santa and Guaraná $(\mathrm{P})$

\begin{tabular}{|c|c|c|c|c|c|}
\hline \multirow{2}{*}{ Element } & \multicolumn{5}{|c|}{ SAMPLE } \\
\hline & Castanha da Índia & Maracujá & Chá verde & Espinheira Santa & Guaraná \\
\hline$\overline{\mathrm{Al}}$ & $153 \pm 6$ & $1364 \pm 49$ & $241 \pm 1$ & $31 \pm 1$ & $381 \pm 14$ \\
\hline As & $<\mathrm{DL}$ & $<\mathrm{DL}$ & $<\mathrm{DL}$ & $<\mathrm{DL}$ & $<\mathrm{DL}$ \\
\hline $\mathrm{Au}$ & $<\mathrm{DL}$ & $<\mathrm{DL}$ & $<\mathrm{DL}$ & $<\mathrm{DL}$ & $<\mathrm{DL}$ \\
\hline $\mathrm{Ba}$ & $<\mathrm{DL}$ & $<\mathrm{DL}$ & $<\mathrm{DL}$ & $<\mathrm{DL}$ & $<\mathrm{DL}$ \\
\hline $\mathrm{Br}$ & $9.5 \pm 0.3$ & $23 \pm 1$ & $1.3 \pm 0.1$ & $<\mathrm{DL}$ & $6 \pm 1$ \\
\hline $\mathrm{Ca}$ & $<\mathrm{DL}$ & $<\mathrm{DL}$ & $<\mathrm{DL}$ & $9877 \pm 600$ & $4890 \pm 461$ \\
\hline $\mathrm{Ce}$ & $<\mathrm{DL}$ & $<\mathrm{DL}$ & $<\mathrm{DL}$ & $0.6 \pm 0.1$ & $0.6 \pm 0.1$ \\
\hline $\mathrm{Cl}$ & $225 \pm 12$ & $5080 \pm 182$ & $447 \pm 2$ & $94 \pm 6$ & $788 \pm 6$ \\
\hline $\mathrm{Co}$ & $0.4 \pm 0.1$ & $0.18 \pm 0.03$ & $0.4 \pm 0.1$ & $0.4 \pm 0.1$ & $0.4 \pm 0.1$ \\
\hline $\mathrm{Cr}$ & $3.7 \pm 0.2$ & $1.4 \pm 0.1$ & $1.7 \pm 0.1$ & $5.3 \pm 0.2$ & $4.9 \pm 0.3$ \\
\hline Cs & $<\mathrm{DL}$ & $0.08 \pm 0.01$ & $0.08 \pm 0.01$ & $0.07 \pm 0.01$ & $0.06 \pm 0.01$ \\
\hline $\mathrm{Fe}$ & $<\mathrm{DL}$ & $<\mathrm{DL}$ & $<\mathrm{DL}$ & $240 \pm 12$ & $230 \pm 12$ \\
\hline $\mathrm{Hf}$ & $0.63 \pm 0.04$ & $<\mathrm{DL}$ & $<\mathrm{DL}$ & $0.06 \pm 0.01$ & $<\mathrm{DL}$ \\
\hline $\mathrm{Hg}$ & $<\mathrm{DL}$ & $<\mathrm{DL}$ & $<\mathrm{DL}$ & $<\mathrm{DL}$ & $0.06 \pm 0.01$ \\
\hline K & $3054 \pm 108$ & $7294 \pm 258$ & $4200 \pm 148$ & $8680 \pm 306$ & $6446 \pm 823$ \\
\hline $\mathrm{La}$ & $<\mathrm{DL}$ & $<\mathrm{DL}$ & $<\mathrm{DL}$ & $0.32 \pm 0.01$ & $<\mathrm{DL}$ \\
\hline $\mathrm{Mg}$ & $219 \pm 17$ & $<\mathrm{DL}$ & $156 \pm 6$ & $130 \pm 8$ & $901 \pm 50$ \\
\hline $\mathrm{Mn}$ & $1.2 \pm 0.1$ & $66 \pm 3$ & $188 \pm 7$ & $24 \pm 1$ & $19 \pm 1$ \\
\hline $\mathrm{Na}$ & $244 \pm 9$ & $670 \pm 23$ & $<\mathrm{DL}$ & $22 \pm 3$ & $<\mathrm{DL}$ \\
\hline $\mathrm{Rb}$ & $<\mathrm{DL}$ & $12 \pm 1$ & $21 \pm 1$ & $24 \pm 1$ & $<\mathrm{DL}$ \\
\hline $\mathrm{Sb}$ & $<\mathrm{DL}$ & $<\mathrm{DL}$ & $<\mathrm{DL}$ & $0.04 \pm 0.01$ & $<\mathrm{DL}$ \\
\hline $\mathrm{Sc}$ & $<\mathrm{DL}$ & $<\mathrm{DL}$ & $0.04 \pm 0.01$ & $0.05 \pm 0.01$ & $<\mathrm{DL}$ \\
\hline $\mathrm{Se}$ & $<\mathrm{DL}$ & $<\mathrm{DL}$ & $<\mathrm{DL}$ & $<\mathrm{DL}$ & $0.05 \pm 0.01$ \\
\hline $\mathrm{Sm}$ & $<\mathrm{DL}$ & $0.02 \pm 0.01$ & $<\mathrm{DL}$ & $<\mathrm{DL}$ & $<\mathrm{DL}$ \\
\hline $\mathrm{Sr}$ & $<\mathrm{DL}$ & $<\mathrm{DL}$ & $<\mathrm{DL}$ & $<\mathrm{DL}$ & $<\mathrm{DL}$ \\
\hline Th & $<\mathrm{DL}$ & $<\mathrm{DL}$ & $<\mathrm{DL}$ & $<\mathrm{DL}$ & $<\mathrm{DL}$ \\
\hline V & $<\mathrm{DL}$ & $<\mathrm{DL}$ & $<\mathrm{DL}$ & $<\mathrm{DL}$ & $0.7 \pm 0.1$ \\
\hline $\mathrm{Zn}$ & $2.9 \pm 0.4$ & $7.4 \pm 0.5$ & $4.5 \pm 0.5$ & $22 \pm 1$ & $21 \pm 1$ \\
\hline
\end{tabular}

$*<$ DL (value under the detection limit).

very low when compared to the average concentration of essential elements for human body like $\mathrm{Cl}, \mathrm{Fe}, \mathrm{K}, \mathrm{Mg}, \mathrm{Mn}$, $\mathrm{Na}$, and $\mathrm{Zn}$, but the diversity of chemical impurities found, even at low concentration levels, considering the potential for chronic toxicity, reinforces the need to improve the implementation of good practices by growers and traders, besides the hypothesis of lack of quality control in plant products. Thus, it is suggested an additional evaluation, since the presence of non-essential elements in plants and herbal medicines can be a problem due to their widespread and long-term use.

\section{ACKNOWLEDGEMENTS}

The authors acknowledge the financial support of FAPEMIG. 
TABLE IV - Elemental concentration ( $\left.\mathrm{mg} \mathrm{kg}^{-1}\right)$ of the samples: Sene, Valeriana (DE), Mulungu (P), Boldo, Erva Cidreira and Espinheira Santa $(\mathrm{T})$

\begin{tabular}{|c|c|c|c|c|c|c|}
\hline \multirow{2}{*}{ Element } & \multicolumn{6}{|c|}{ SAMPLE } \\
\hline & Sene & Valeriana & Mulungu & Esp. Santa & Erva Cidreira & Boldo \\
\hline$\overline{\mathrm{Al}}$ & $198 \pm 7$ & $294 \pm 11$ & $658 \pm 24$ & $298 \pm 12$ & $1571 \pm 61$ & $1190 \pm 44$ \\
\hline As & $<\mathrm{DL}$ & $<\mathrm{DL}$ & $<\mathrm{DL}$ & $0.12 \pm 0.01$ & $1.3 \pm 0.1$ & $<\mathrm{DL}$ \\
\hline $\mathrm{Au}$ & $<\mathrm{DL}$ & $<\mathrm{DL}$ & $<\mathrm{DL}$ & $<\mathrm{DL}$ & $0.01 \pm 0.01$ & $<\mathrm{DL}$ \\
\hline $\mathrm{Ba}$ & $<\mathrm{DL}$ & $<\mathrm{DL}$ & $540 \pm 19$ & $35 \pm 9$ & $<\mathrm{DL}$ & $37 \pm 3$ \\
\hline $\mathrm{Br}$ & $15.26 \pm 0.54$ & $6.5 \pm 0.2$ & $13.2 \pm 0.5$ & $6.8 \pm 0.2$ & $3.4 \pm 0.1$ & $25 \pm 1$ \\
\hline $\mathrm{Ca}$ & $<\mathrm{DL}$ & $<\mathrm{DL}$ & $21150 \pm 919$ & $9647 \pm 1355$ & $22136 \pm 1914$ & $11110 \pm 768$ \\
\hline $\mathrm{Ce}$ & $<\mathrm{DL}$ & $0.58 \pm 0.04$ & $2.7 \pm 0.1$ & $1.5 \pm 0.1$ & $<\mathrm{DL}$ & $0.9 \pm 0.1$ \\
\hline $\mathrm{Cl}$ & $225 \pm 13$ & $1703 \pm 66$ & $3953 \pm 151$ & $1852 \pm 75$ & $5988 \pm 222$ & $2675 \pm 148$ \\
\hline Co & $0.4 \pm 0.1$ & $0.7 \pm 0.1$ & $2.5 \pm 0.1$ & $0.09 \pm 0.01$ & $1.9 \pm 0.1$ & $0.15 \pm 0.01$ \\
\hline $\mathrm{Cr}$ & $5.3 \pm 0.2$ & $5.6 \pm 0.2$ & $2.5 \pm 0.1$ & $4.3 \pm 0.2$ & $132 \pm 5$ & $0.6 \pm 0.1$ \\
\hline Cs & $<\mathrm{DL}$ & $<\mathrm{DL}$ & $<\mathrm{DL}$ & $0.14 \pm 0.01$ & $0.19 \pm 0.01$ & $0.05 \pm 0.01$ \\
\hline $\mathrm{Fe}$ & $<\mathrm{DL}$ & $<\mathrm{DL}$ & $360 \pm 16$ & $210 \pm 10$ & $2499 \pm 90$ & $393 \pm 17$ \\
\hline Hf & $<\mathrm{DL}$ & $<\mathrm{DL}$ & $0.65 \pm 0.04$ & $<\mathrm{DL}$ & $0.23 \pm 0.01$ & $0.05 \pm 0.01$ \\
\hline $\mathrm{Hg}$ & $<\mathrm{DL}$ & $<\mathrm{DL}$ & $<\mathrm{DL}$ & $<\mathrm{DL}$ & $<\mathrm{DL}$ & $<\mathrm{DL}$ \\
\hline K & $3949 \pm 145$ & $6132 \pm 225$ & $12220 \pm 1024$ & $8909 \pm 324$ & $17850 \pm 649$ & $10510 \pm 374$ \\
\hline $\mathrm{La}$ & $<\mathrm{DL}$ & $0.19 \pm 0.02$ & $1.7 \pm 0.1$ & $0.57 \pm 0.02$ & $0.77 \pm 0.03$ & $0.87 \pm 0.03$ \\
\hline $\mathrm{Mg}$ & $886 \pm 40$ & $616 \pm 31$ & $1044 \pm 59$ & $1256 \pm 70$ & $5287 \pm 241$ & $1946 \pm 175$ \\
\hline $\mathrm{Mn}$ & $5.2 \pm 0.2$ & $29 \pm 1$ & $50 \pm 2$ & $202 \pm 7$ & $202 \pm 7$ & $113 \pm 4$ \\
\hline $\mathrm{Na}$ & $763 \pm 27$ & $220 \pm 10$ & $195 \pm 8$ & $11.7 \pm 0.4$ & $22 \pm 1$ & $59 \pm 2$ \\
\hline $\mathrm{Rb}$ & $<\mathrm{DL}$ & $6.7 \pm 0.4$ & $13.1 \pm 0.6$ & $<\mathrm{DL}$ & $<\mathrm{DL}$ & $<\mathrm{DL}$ \\
\hline $\mathrm{Sb}$ & $<\mathrm{DL}$ & $<\mathrm{DL}$ & $<\mathrm{DL}$ & $<\mathrm{DL}$ & $<\mathrm{DL}$ & $<\mathrm{DL}$ \\
\hline $\mathrm{Sc}$ & $<\mathrm{DL}$ & $0.03 \pm 0.01$ & $0.07 \pm 0.04$ & $0.02 \pm 0.01$ & $0.23 \pm 0.01$ & $0.13 \pm 0.01$ \\
\hline $\mathrm{Se}$ & $<\mathrm{DL}$ & $0.05 \pm 0.01$ & $<\mathrm{DL}$ & & & \\
\hline $\mathrm{Sm}$ & $<\mathrm{DL}$ & $<\mathrm{DL}$ & $0.10 \pm 0.04$ & $0.16 \pm 0.01$ & $0.09 \pm 0.01$ & $0.10 \pm 0.01$ \\
\hline $\mathrm{Sr}$ & $<\mathrm{DL}$ & $<\mathrm{DL}$ & $405 \pm 17$ & $<\mathrm{DL}$ & $<\mathrm{DL}$ & $98 \pm 5$ \\
\hline Th & $<\mathrm{DL}$ & $0.04 \pm 0.01$ & $0.25 \pm 0.01$ & $<\mathrm{DL}$ & $0.15 \pm 0.02$ & $0.10 \pm 0.01$ \\
\hline V & $<\mathrm{DL}$ & $<\mathrm{DL}$ & $<\mathrm{DL}$ & $<\mathrm{DL}$ & $<\mathrm{DL}$ & $<\mathrm{DL}$ \\
\hline $\mathrm{Zn}$ & $<\mathrm{DL}$ & $4.7 \pm 0.4$ & $11 \pm 1$ & $22 \pm 1$ & $46.8 \pm 1.9$ & $23 \pm 1$ \\
\hline
\end{tabular}

$*<$ DL (value under the detection limit).

\section{REFERENCES}

ALWAKEEL, S.S. Microbial and heavy metals contamination of herbal medicines. Res. J. Microbiol., v.3, n.12, p.683$691,2008$.

AZEVEDO, F.A.; CHASIN, A.A.M. As bases toxicológicas da ecotoxicologia. São Paulo: Rima Intertox, 2003. 340 p.
BALBINO, E.E.; DIAS, M.F. Farmacovigilância: um passo em direção ao uso racional de plantas medicinais e fitoterápicos. Rev. Bras. Farmacogn., v.20, n.6, p.992-1000, 2010.

BRASIL. Ministério da Saúde. Agência Nacional de Vigilância Sanitária. Gerência Geral de Medicamentos. Gerência de Tecnologia Farmacêutica. Coordenação de Fitoterápicos, Dinamizados e Notificados (COFID). Consolidado de Normas da COFID. Versão III, Brasília, DF, 2010a. 
BRASIL. Ministério da Saúde. Agência Nacional de Vigilância Sanitária. Instrução Normativa - IN n ${ }^{\circ}$. 5, de 31 de março de 2010. Estabelece a lista de referências bibliográficas para avaliação de segurança e eficácia de medicamentos fitoterápicos. Diário Oficial da União, Poder Executivo, Brasília, DF, 2010b.

BRASIL. Ministério da Saúde. Agência Nacional de Vigilância Sanitária. Resolução de Diretoria Colegiada-RDC n . 10, de 9 de março de 2010. Dispõe sobre a notificação de drogas vegetais junto à Agência Nacional de Vigilância Sanitária (ANVISA) e dá outras providências. Diário Oficial da União, Poder Executivo, Brasília, DF, Seção 1, 2010c.

BRASIL. Ministério da Saúde. Agência Nacional de Vigilância Sanitária. Resolução de Diretoria Colegiada - RDC n ${ }^{\circ}$. 14, de 31 de março de 2010. Dispõe sobre o registro de medicamentos fitoterápicos. Diário Oficial da União, Poder Executivo, Brasília, DF, Seção 1, 2010d.

BUGNO, A.; BUZZO, A.A.; NAKAMURA, C.T.; PEREIRA, T.C.; MATOS, D.; PINTO, T.J.A. Avaliação da contaminação microbiana em drogas vegetais. Rev. Bras. Ciênc. Farm., v.41, n.4, p.491-497, 2005.

CALDAS, E.D.; MACHADO, L.L. Cadmium, Mercury and lead in medicinal herbs in Brazil. Food Chem. Toxicol., v.42, n.4, p.599-603, 2004.

CARVALHO, A.C.B.; PERFEITO, J.P.S.; SILVA, L.V.C.; RAMALHO, L.S.; MARQUES, R.F.O.; SILVEIRA, D. Regulation of herbal medicines in Brazil: advances and perspectives. Braz. J. Pharm. Sci., v.47, n.3, p.467-473, 2011.

CARVALHO, C.M.G.; PRUDENTE, L.R.; PEREIRA, A.C.; PAULA, J.R.; BARA, M.T.F. Avaliação da qualidade de extratos vegetais. Rev. Eletr. Farm., v.3, n.2, p.53-62, 2006.

CARVALHO, L.M.; COSTA, J.A.M.; CARNELOSSI, M.A.G. Qualidade em plantas medicinais. Aracaju: Embrapa Tabuleiros Costeiros, 2010. 54 p.

DOSPATLIEV, L.; KOSTADINOV, K.; MIHAYLOVA, G.; KATRANDZHIEV, N. Determination of heavy metals ( $\mathrm{Pb}, \mathrm{Zn}, \mathrm{Cd}$ and $\mathrm{Ni}$ ) in eggplant. Trak. J. Sci., v.10, n.2, p.31-35, 2012.

ERNST, E. Toxic heavy metals and undeclared drugs in Asian herbal medicines. Trends Pharmacol. Sci., v.23, n.3, p.136$139,2002$.
FERGUSSON, J.E. The heavy elements: chemistry, environmental impact and health effects. Oxford: Pergamon Press, 1990.614 p.

FITOTERÁPICOS americanos têm metais pesados. Veja online, 26 de maio de 2010. Available at: <http://veja.abril. com.br/noticia/saude/fitoterapicos-americanos-tem-metaispesados $>$. Accessed on: 19 Sept. 2012.

FRAGA, C.G. Relevance, essentiality and toxicity of trace elements in human health. Mol. Aspects Med., v.26, n.3-4, p.235-244, 2005.

FREIRE, M.F.I. Metais pesados e plantas medicinais. Rev. Cient. Eletr. Agron., ano IV, n.8, p.1-14, 2005.

GAUTAM, A.; KASHYAP, S.J.; SHARMA, P.K.; GARG, V.K.; VISHT, S.; KUMAR, N. Identification, evaluation and standardization of herbal drugs: a review. Der Pharmacia Lettre, v.2, n.6, p.302-315, 2010.

HUSSAIN, I.; KHAN, F.; KHAN, I.; KHAN, L.; WALIULLAH, J. Determination of heavy metals in medicinal plants. J. Chem. Soc. Pak., v.28, n.4, p.347-351, 2006.

JABEEN, S.; SHAH, M.T.; KHAN, S.; HAYAT, M.Q. Determination of major and trace elements in ten important folk therapeutic plants of Haripur basin, Pakistan. J. Med. Plant. Res., v.4, n.7, p.559-566, 2010.

JULIÃO, L.S.; TAVARES, E.S.; LAGE, C.L.S.; LEITÃO, S.G. Cromatografia em camada fina de extratos de três quimiotipos de Lippia alba (Mill) N.E.Br. (erva-cidreira). Rev. Bras. Farmacogn., v.13, suppl.1, p.36-38, 2003.

KUSKOSKI, E.M.; ROSEANE, F.; GARCÍA, A.A.; TRONCOSO, G.A.M. Propriedades químicas e farmacológicas del fruto guaraná (Paullinia cupana). Vitae, v.12, n.2, p.45-52, 2005.

LANGILLE, W.M.; MACLEAN, K.S. Some essential nutrient elements in forest plants as related to species, plant part, season and location. Plant Soil, v.45, p.17-26, 1976.

LANINI, J.; DUARTE-ALMEIDA, J.M.; NAPPO, S.; CARLINI, E.A. "O que vêm da terra não faz mal" - relatos de problemas relacionados ao uso de plantas medicinais por raizeiros de Diadema/SP. Rev. Bras. Farmacogn., v.19, n.1, p.121-129, 2009. 
LEAL, A.S.; MENEZES, M.Â.B.C.; RODRIGUES, R.R.; ANDONIE, O.; VERMAERCKE, P.; SNEYERS, L. A comparative neutron activation analysis study of common generic manipulated and reference medicines commercialized in Brazil. Appl. Radiat. Isot., v.66, n.10, p.1307-1312, 2008.

LEAL, A.S.; MENEZES, M.Â.B.C.; VERMAERCKE, P.; SNEYERS, L.; JENSEN, C.E.M. Investigation of chemical impurities in formulations, phytotherapics and polyvitaminic medicines by $k_{0}$-instrumental neutron activation analysis. Nucl. Instrum. Methods Phys. Res., Sect.A, v.564, n.2, p.729-732, 2006.

LOKESHAPPA, B.; SHIVPURI, K; TRIPATHI, V.; DIKSHIT, A.K. Assessment of toxic metals in agricultural produce. Food Pub. Health, v.2, n.1, p.24-29, 2012.

MARTINS, E.L.P.; BRANDÃO, M.G.L. Qualidade de amostras comerciais preparadas com Aesculus hippocastanum L. (castanha-da-Índia). Rev. Bras. Farmacogn., v.16, n.2, p.224-229, 2006.

MEMON, A.R.; AKTOPRAKLIGUL, D.; ZDEMUR, A.; VERTII, A.; BUTAK, T. Heavy metal accumulation and detoxication mechanisms in plants. Turk. J. Bot., v.25, p.111-121, 2001.

MELO, J.G.; NASCIMENTO, V.T.; AMORIM, E.L.C.; LIMA, C.S.A.; ALBUQUERQUE, U.P. Avaliação da qualidade de amostras comerciais de boldo (Peumus boldus Molina), pata-de-vaca (Bauhinia spp.) e ginco (Ginkgo biloba L.). Rev. Bras. Farmacogn., v.14, n.2, p.111-120, 2004.

MENEZES, M.Â.B.C.; JACIMOVIC, R. Optimised $k_{0}$ instrumental neutron activation method using the TRIGA MARK I IPR-R1 reactor at CDTN/CNEN, Belo Horizonte, Brazil. Nucl. Instrum. Methods Phys. Res., Sect.A, v.564, n.2, p.707-715, 2006.

NEGRI, M.L.S.; POSSAMAI, J.C.; NAKASHIMA, T. Atividade antioxidante das folhas de espinheira-santa Maytenus ilicifolia Mart. ex Reiss., secas em diferentes temperaturas. Rev. Bras. Farmacogn., v.19, n.2b, p.553$556,2009$.
NISHIYAMA, M.F.; COSTA, M.A.F.; COSTA, A.M.; SOUZA, C.G.M.; BÔER, C.G.; BRACHT, C.K.; PERALTA, R.M. Chá verde brasileiro (Camellia sinensis var assamica): efeitos do tempo de infusão, acondicionamento da erva e forma de preparo sobre a eficiência de extração dos bioativos e sobre a estabilidade da bebida. Ciênc. Tecnol. Aliment., v.30, supl.1, p.191-196, 2010.

PARIS, F.; PETRY, R.D.; REGINATTO, F.H.; GOSMANN, G.; QUEVEDO, J.; SALGUEIRO, J.B.; KAPCZINSKI, F.; ORTEGA, G.G.; SCHENKEL, E.P. Pharmacochemical study of aqueous extracts in Passiflora alata Dryander and Passiflora edulis Sims. Acta Farm. Bon., v.21, n.1, p.5-8, 2002.

PERON,A.P.; MARCOS, M.C.; CARDOSO, S.C.; VICENTINI, V.E.P. Avaliação do potencial critotóxico dos chás de Camellia sinensis L. e Cassia angustifólia vahl em sistema teste vegetal. Arq. Ciênc. Saúde UNIPAR, v.12, n.1, p.5154, 2008.

PLANTAMED. Fitoterapia e plantas medicinais, 14 fev. 2013. Available at: <http://www.plantamed.com.br/plantaservas/ especies/index_nc.html > Accessed on: 18 Feb. 2013.

REMINGTON, J.P.; GENARO, A.R. The science and practice of pharmacy. 20.ed. Philadelphia: Philadelphia College of Pharmacy and Science, 2000. 2077 p.

RUBIO, C.; LUCAS, J.R.D.; GUTIÉRREZ, A.J.; GLEZWELLER, D.; PÉREZ MARRERO, B.; CABALLERO, J.M.; REVERT, C.; HARDISSON, A. Evaluation of metal concentrations in mentha herbal teas (Mentha piperita, Mentha pulegium and Mentha species) by inductively coupled plasma spectrometry. J. Pharm. Biomed. Anal., v.71, p.11-17, 2012.

SIMÕES, C.M.O.; SCHENKEL, E.P.; GOSMANN, G.; MELLO, J.C.P.; MENTZ, L.A.; PETROVICK, P.R. (Eds.) Farmacognosia da planta ao medicamento. 5.ed. Florianópolis: Editora da UFSC; Porto Alegre: Editora da UFRGS, 2003. 1097 p.

SILVEIRA, P.F.; BANDEIRA, M.A.M.; ARRAIS, P.S.D. Farmacovigilância e reações adversas às plantas medicinais e fitoterápicas: uma realidade. Rev. Bras. Farmacogn., v.18, n.4, p.618-626, 2008. 
SOUZA-MOREIRA, T.M.; SALGADO, H.R.N.; PIETRO, R.C.L.R. O Brasil no contexto de controle de qualidade de plantas medicinais. Rev. Bras. Farmacogn., v.20, n.3, p.435-440, 2010.

TOBIAS, M.L.; OLIVEIRA, F.; OLIVEIRA, K.P.; MARQUES, L.C. Controle de qualidade de drogas vegetais de farmácias de manipulação de Maringá (Paraná - Brasil). Rev. Eletr. Farm., v.4, n.1, p.95-103, 2007.

VEIGA JR, V.F.; PINTO, A.C.; MACIEL, M.A.M. Plantas medicinais: cura segura? Quím. Nova, v.28, n.3, p.519$528,2005$.

VIEGAS JR, C.; BOLZANI, V.S.; BARREIRO, E.J. Os produtos naturais e a química medicinal moderna. Quim. Nova, v.29, n.2, p.326-337, 2006.

VIRTUOSO, S.; DAVET, A.; DIAS, J.F.G.; CUNICO, M.M.; MIGUEL, M.D.; OLIVEIRA, A.B.; MIGUEL, O.G. Estudo preliminar da atividade antibacteriana das cascas de Erythrina velutina Willd., Fabaceae (Leguminosae). Rev. Bras. Farmacogn., v.15, n.2, p.137-142, 2005.

VULCANO, I.R.C.; SILVEIRA, J.N.; ALVAREZ-LEITE, E.M. Teores de chumbo e cádmio em chás comercializados na região metropolitana de Belo Horizonte. Braz. J. Pharm. Sci.,v.44, n.3, p.425-431, 2008.

WORLD HEALTH ORGANIZATION. Guidelines on good agricultural and collection practices (GACP) for medicinal plants. Geneva: WHO, 2003. 72 p.
WORLD HEALTH ORGANIZATION. Guidelines on safety monitoring of herbal medicines in pharmacovigilance systems. Geneva: WHO, 2004. 68 p.

WORLD HEALTH ORGANIZATION. The importance of pharmacovigilance - safety monitoring of medicinal products. Geneva: WHO, 2002. 52 p.

YADAV, P.; PRAJAPATI, P.K. Quality control parameters for medicinal plants, an overview. Asian J. Biomed. Pharm. Sci, v.1, n.5, p.12-16, 2011.

YAMASHITA, C.I.; SAIKI, M.; VASCONCELLOS, M.B.; SERTIÉ, J.A. Characterization of trace elements in Casearia medicinal plant by neutron activation analysis. Appl. Radiat. Isot., v.63, n.5-6, p.841-846, 2005.

YUAN, X.; CHAPMAN, R.L.; WU, Z. Analytical methods for heavy metals in herbal medicines. Phytochem. Analysis, v.22, n.3, p.189-198, 2011.

ZARONI, M.; PONTAROLO, R.; ABRAHÃO, W.S.M.; FÁVERO, M.L.D.; CORREA JR, C.; STREMEL, D.P. Qualidade microbiológica das plantas medicinais produzidas no estado do Paraná. Rev. Bras. Farmacogn., v.14, n.1, p.29-39, 2004.

ZHANG, J.; WIDER, B.; SHANG, H.; LI, X.; ERNST, E. Quality of herbal medicines: challenges and solutions. Complement. Ther. Med., v.20, n.1, p.100-106, 2012.

Received for publication on: $14^{\text {th }}$ November 2012 Accepted for publication on: 17 April 2013 